$\mathbb{T}$ periodica polytechnica

\author{
Civil Engineering \\ $56 / 1$ (2012) 107 113 \\ doi: 10.3311/pp.ci.2012-1.12 \\ web: http://www.pp.bme.hu/ci \\ (c) Periodica Polytechnica 2012
}

RESEARCH ARTICLE

\section{Characterization of piping with grading entropy on the Surány example}

\author{
László Nagy
}

Received 2011-07-07, revised 2011-10-12, accepted 2012-02-06

\begin{abstract}
Grain size and grain distribution by size are dominant factors determining soil behaviour. The shape and position of a grain distribution curve contain implicit information about the propensity of sand boiling or piping at flood conditions. The author used 104 grain distribution curves taken from 12 sand boil locations to study the relationship between sand boils, hydraulic soil failures and entropy. The results have justified the hypotheses and indicated some fairly important details for practical consideration. Calculating grain distribution entropy is not "magic" with mathematics: it simply helps put the expected behaviour of soils into a different perspective and promotes orientation for classifying soils according to a new parameter related to grain movement.
\end{abstract}

\section{Keywords}

Entropy $\cdot$ grain size distribution $\cdot$ practical evaluation $\cdot$ piping hydraulic failure

\section{László Nagy}

BME Geotechnical Department, H-1111 Bp Múegyetem rkp 5-7, Hungary e-mail: lacinagy@mail.bme.hu

\section{Introduction}

Boil formation and sand boiling failures are relatively infrequent loss events in the history of dike breaches in Hungary. Boils normally form in intersections with old riverbeds in locations where one can observe the intercalation of grainier soil, which is different from its environment [9]. Past experience suggests that only a small percentage of boils actually terminated in disaster [10], the threat has been localised most of the time (presumably due to efficient flood control measures, e.g. the boil at Csongrád in Fig. 11. A series of detailed subsoil studies [8] performed along $4200 \mathrm{~km}$ of Hungarian flood control dikes between 1984 and 1996 revealed that the number of shorter or longer sections with soil failure potential is so large (over 1500) that efficient protection can only be expected at locations where the phenomena associated with boil formation are visible.

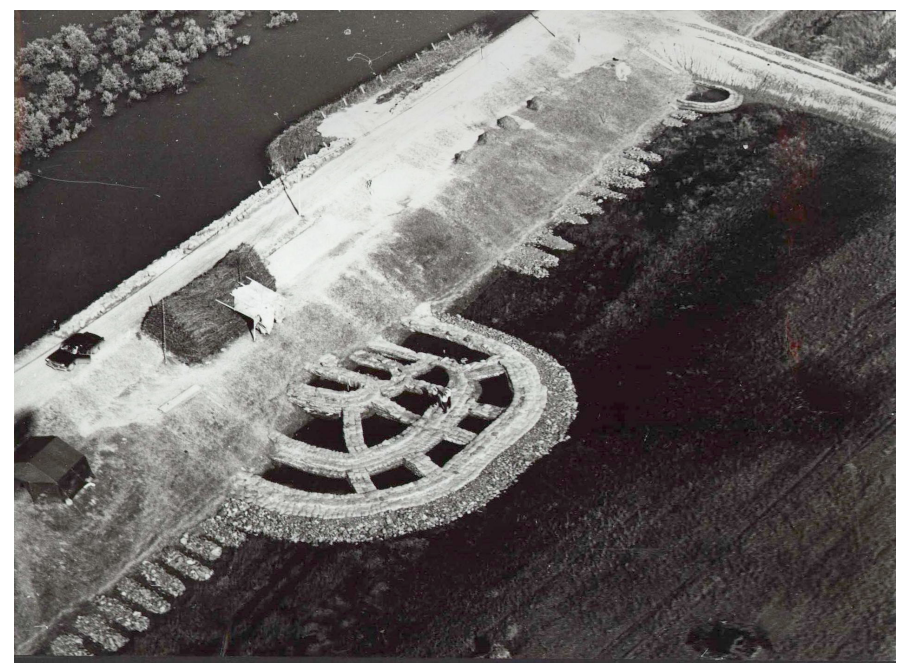

Fig. 1. The Csongrád piping in 1970 after peaking

Grain size and grain distribution by size are dominant factors determining soil behaviour. The distribution of soil grains by size has been studied for a long time and grainy soils are named based on information provided by grain distribution curves. The direct of use the various parameters of a grain distribution curve, such as grain sizes associated with percentage values, the coefficient of irregularity, etc. is mostly limited to judging compactability and various water and grain movement phenomena. 
Indeed, these quantities provide a relatively good characterization of soils with grain distribution curves showing calm, regular shapes or a narrower diameter range, but the rules derived from these relationships lose validity as soon as grain distribution is irregular, i.e. the rules have no general validity. Taking the grain distribution curve fully into account would obviously improve the accuracy of rules based on grain distribution, such as the calculation of permeability.

\section{The definition of entropy}

Entropy is a term used to describe the degree of disorder of a statistical population in the theory of probability. It is easy to calculate it for the grain distribution of soils. The distribution by size of grains in a soil is determined by fractioning with a set of screens or a sedimentation experiment or frequently by using both methods simultaneously.

When soils are screened, each frequency value will reflect the proportion of the total screened volume that belongs to a screened fraction. Frequencies are added up based on the fractions falling through the screens that correspond to fraction boudaries and by doing so we get a grain distribution curve [3, 4].

The closer the aperture size of the screens in a stack, i.e. the narrower the fractions are, the greater the accuracy of the ordinates of a grain distribution curve will be. As there is not much practical use of narrowing fractions down, the following aperture sizes in a screen set are becoming quite standard in Hungary:

$$
d(\mathrm{~mm})=(0.063), 0.125,0.25,0.5,1,2,4,8, \ldots,
$$

That is to say, the aperture size of the next screen in a set is twice the aperture size of the previous screen.

The calculation method introduced to determine the grain distribution entropy of soils is based on the assumption that the screen set described above has been used, and in case another screen set was used for the purposes of identifying grain distribution, the grain distribution curve itself will have to be split at the fraction boundaries and then calculate the frequency of the resulting fractions.

As each fraction covers a different width diameter range, the $\mathrm{C}$ number of elementary cells in a fraction will vary in case $\mathrm{z}$ elementary cell width is identical [3, 4]. To ensure that subsequent calculations suitable for determining the grain distribution entropy of even colloid state substances (i.e. that they have positive entropy) we need to select an extremely small $z$ elemental cell width. The following elemental cell width was applied:

$$
z=2^{-17} \mathrm{~mm}
$$

It is worth mentioning that elemental cell width was set at $z=$ $2^{-22} \mathrm{~mm}$ in other application areas of grain distribution entropy mainly to ensure the comprehensive use and generalization of the term [5, ?6]. The value selected for this study $\left(z=2^{-17}\right)$ is suitable for the purpose as we examined the behaviour of natural soils.

\section{Intrinsic entropy}

The mass of grains in the elementary cells of a fraction with uniform distribution will be equal, i.e. the frequency of every elementary cell is identical [3, 4]:

$$
\alpha=\frac{1}{C}
$$

where $\mathrm{C}$ is the number of elementary cells in a fraction. The intrinsic entropy of fraction $i$ is:

$$
S_{0 i}=-\frac{1}{\ln 2} C i\left(\frac{1}{C i} \ln \frac{1}{C i}\right)
$$

hence:

$$
S_{0 i}=\frac{\ln C i}{\ln 2}
$$

To illustrate the above, let us calculate the intrinsic entropy of a few screened fractions.

- the diameter range of the $1-2 \mathrm{~mm}$ fraction is $1 \mathrm{~mm}$.

- the number of elementary cells in this fraction is:

$C=\frac{1 \mathrm{~mm}}{2^{-17} \mathrm{~mm}}=2^{17}$ cells (4)

- intrinsic entropy:

$$
S_{0}^{1-2}=\frac{\ln 2^{17}}{\ln 2}=\frac{17 \ln 2}{\ln 2}=17
$$

The intrinsic entropy of the $2-4 \mathrm{~mm}$ fraction is:

$$
C=\frac{2 \mathrm{~mm}}{2^{-17} \mathrm{~mm}}=2 * 2^{18}
$$

$$
S_{0}^{2-4}=18
$$

and so on.

The difference between the intrinsic entropy values of subsequent fractions is 1 . That is due to doubling the width of subsequent fractions and, concurrently, the radix of the logarithm is also 2

Fig. 2 shows the intrinsic entropy $S_{0}$ and cell numbers $C_{i}$ of the fractions for the recommended and applied elementary cell width $z$.

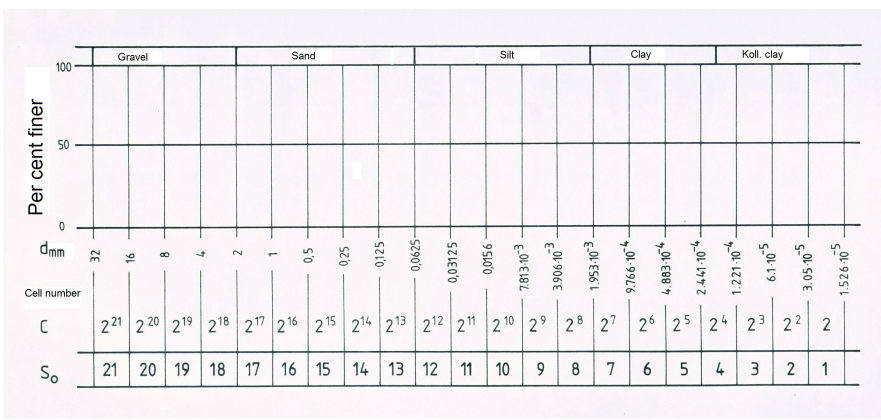

Fig. 2. The intrinsic entropy and cell numbers

\section{The entropy of soils split into fractions}

Screens are used to split the soil into fractions or the grain distribution curve derived from a sedimentation experiment is "fractioned off", while distribution within fraction boundaries is 
assumed to be uniform. The frequency of fraction $i$ is represented as $x_{i}$.

$$
\sum_{l=1}^{n} x_{1}=1
$$

Hence respective fraction frequencies are: $x_{1}, x_{2}, \ldots, x_{n}$. The number of elementary cells in fraction $i$ is $C_{i}$. In the case of uniform internal distribution in the fractions, the intrinsic frequency of these cells is:

$$
\alpha_{1}=\frac{x_{1}}{C_{1}}, \alpha_{2}=\frac{x_{2}}{C_{2}}, \ldots, \alpha_{n}=\frac{x_{n}}{C_{n}}
$$

Entropy value is:

$$
S=-\frac{1}{\ln 2} \sum_{i=1}^{n} x_{i} \ln x_{i}+\frac{1}{\ln 2} \sum_{i=1}^{n} x_{i} \ln C i
$$

A comparison of the first addend with formula (3) reveals that it is nothing else but the $\Delta S$ increment of entropy growth resulting from mixing the fractions.

Let us select element $i$ from the second addend of the formula:

$$
x_{i} \frac{\ln C_{i}}{\ln 2}=x_{i} S_{0 i}
$$

see formula (13).

Hence, this is the product of multiplying the intrinsic entropy of fraction $i$ with the frequency of the same fraction. Accordingly, the second addend of expression (9) can be rearranged as follows:

$$
S_{0}=\sum_{i=1}^{n} x_{i} S_{0 i}
$$

where $x_{i}=$ the frequency of fraction $i$,

$S_{0 i}=$ the intrinsic entropy of fraction $i$.

We call this entropy $S_{0}$ of the soil before mixing base-entropy.

\section{Increment of entropy $\Delta S$}

We can say based on the entire formula (9) that soil grain distribution entropy equals the sum of the base-entropy before mixing and the incremental entropy growth that results from mixing [1]:

$$
S=S_{0}+\Delta S
$$

Based on the definition, incremental entropy growth $\Delta S$ is:

$$
\Delta S=-\frac{1}{\ln 2} \sum_{i=1}^{n} x_{i} \ln x_{i}
$$

When two systems are mixed, the grain distribution entropy of the resulting mixture will remain unchanged or will increase. If a soil is mixed with itself, the grain distribution entropy of the "mixture" will not change, whilst mixing different soil types will always result in entropy growth. Fig. 3 shows the increments of entropy growth as a function of the ratio of mixing. Entropy growth reaches its maximum at 50-50\% mixing ratio.

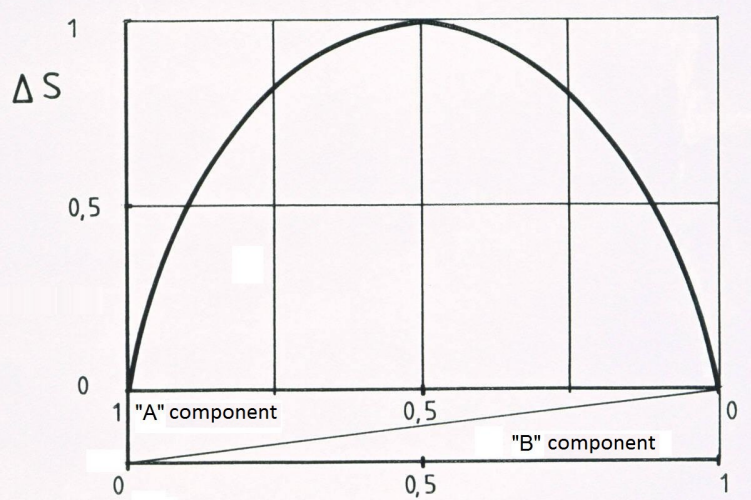

Fig. 3. The increments of entropy growth

\section{Change of entropy growth}

As Fig. 3 suggests, the entropy of a mixture containing two components, both with zero entropy, will change in line with the ratio of mixing and will peak when the ratio of the two components is the same. Increasing the number of components will result in an absolute increase of incremental entropy growth (or mixing entropy). The incremental entropy growth of mixtures containing an arbitrary number of components will reach a maximum when the frequency of the fractions is identical, i.e. with $F$ as the number of fractions, then in case:

$$
x_{1}=x_{2}=\ldots=x_{F}=\frac{1}{F}
$$

Using these frequencies, the incremental value is:

$$
\Delta S_{\max }=-\frac{1}{\ln 2} F\left(\frac{1}{F} \ln \frac{1}{F}\right)
$$

hence

$$
\Delta S_{\max }=\frac{\ln F}{\ln 2} .
$$

The maximum incremental entropy growth for a given width range is obtained when fraction frequencies are identical. Maximum entropy growth depends on the fraction number $F$. Fig. 4 shows the effect of the number of fractions in a mixture on the maximum value of mixing entropy.

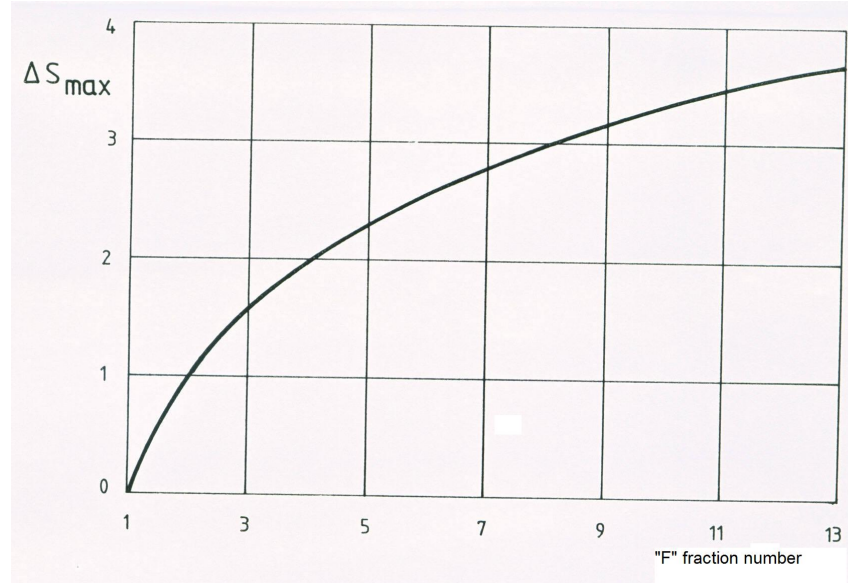

Fig. 4. The effect of the number of fractions in a mixture 
Based on the findings of a large number of laboratory mixing experiments we can safely say that the soil with $S_{0}$ base-entropy at close to $2 / 3$ of the range will provide the most compact skeleton from among the possible infinite number of mixtures of different grain distribution within a range of grain width [3, 4], i.e.

$$
S_{0}=S_{0 \min }+2 / 3\left(S_{0 \max }-S_{0 \min }\right)
$$

where $S_{0 \max }=$ the intrinsic entropy of the coarsest soil fraction, and $S_{0 \min }=$ the intrinsic entropy of the finest soil fraction.

\section{Applying grain distribution entropy to transient phe- nomena}

If grains can be washed out of a soil, grain distribution will be altered and the original conditions of grain distribution will not be upheld any longer. Only soils that withstand suffusion are suitable for the purpose of soil filtration, and designs rely on their grain distribution [2,5].

Demixing may occur during filter placement, which may lead to a complete modification of the parameters taken into account during screening tests. Earlier experience [3, 4] suggests that soils with grain distribution curves covering ranges of 4 or fewer fractions either continuously or incompletely are not susceptible to suffusion, because the coarsest fraction of the range of 4 fractions can be used as the filter of the finest fraction. It is obvious that no mixture of these fractions, regardless of proportion, lends itself to suffusion. The propensity to suffusion can be studied on the basis of the grain distribution curve of soils covering ranges wider than 5 fractions. Including $\Delta S / \ln F$ values, Fig. 5 helps evaluate internal grain movements ( $\Delta S$ stands for entropy growth, $F$ represents the number of all fractions potentially included in a grain distribution range), which can be calculated with this equation:

$$
A=\frac{S_{0}-S_{0 \min }}{S_{0 \max }-S_{0 \min }}
$$

depending on normalised entropy. The curve shows symmetry with the axis $A=0.5$, curve data include the $\Delta S / \ln F$ values of what are known as distributions with "optimal" entropy.

In Fig. 5, the ranges labelled "sand boil", "stable" and "suffusion" have been identified based on a large number of experiments [3]. Each point in the figure represents a shape of a grain distribution curve, i.e. the Fig. is the representation of an infinite number of parallel grain distribution curves. Points $\mathbf{A}, \mathbf{B}, \mathbf{C}$ and $\mathbf{D}$ are highlighted in the figure:

- Point D represents a 1/3-2/3 mixture of only two (the finest and the coarsest) of fractions of a range covering 5 fractions with the following coordinates: $A=2 / 3, \Delta S / \ln F=0.571$.

- Point A stands for grain distribution curves containing any number of fractions, but each fraction is identically filled (see Fig. 5).

- Point $\mathbf{B}$ corresponds to soils with $2 / 3$ grain distribution.
- $\mathbf{C}$ shows the point of grain distribution at which entropy is at its maximum, the coordinates in the present representation are: $A=0.79, \Delta S / \ln F=1.167$, with larger fraction numbers the point shifts towards $A=1$ on the curve.

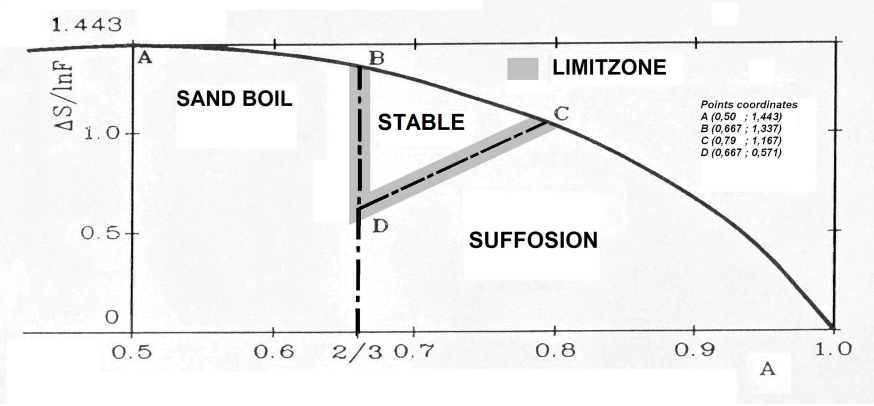

Fig. 5. The characterization of granular soils by entropy

Experience suggests that fine grains form a matrix before point $\mathbf{B}$ in case $A<2 / 3$, they "lift to disaggregate" the coarse skeleton and the further away the point is from $A=2 / 3$ in the direction of $A=0$ the more intensive the floatation of coarse grains in the matrix.

If scouring occurs in soils with the propensity to boil, the value of $A$ converges towards 0.5 in the ranges affected by scouring. Scouring with hydraulic failure shows the same features regardless of the original value of $A$ !

The transition from the matrix of fine grains to coarse grained skeleton starts above $A=2 / 3$. The transition is very sharp in mixtures of two fractions and fractions missing, if $A$ is only slightly larger than $2 / 3$, a rough skeleton gets formed and fine grains can freely move or get scoured away.

Transition occurs within the B-C-D range in soils with continuous grain distribution. In terms of grain movement this range may be called safe as fine grains do not form a matrix any longer and no coarse skeleton builds up yet.

Grain distributions beyond point $\mathbf{C}$ and those on the right hand side of the $\mathbf{C D}$ line show a skeleton formed by coarse grains with the majority of fine grains allowed to move freely, hence grain movement and suffusion will begin among proper circumstances. Normally, relatively small quantities get scoured away, although larger volumes may also get dislodged from soils with missing size fractions.

It is validly observed both as regards the sand boil and the suffusion ranges that the soils in the vicinity of the top boundary curve, which represents the soil types with optimum entropy, are safer, and the threat of scouring increases as we move further away from the boundary curve and the lines at which ranges terminate.

In the case of hydraulic soil failure, i.e. when soils are completely remixed and restructured, the point representing the soil moves towards a position where $A=0.5$ regardless of its former position. Changes are of different character with samples taken from below the waterline. In this case, if the sampling device is not closed, fine grains are washed away while the sample 
is lifted and grain distribution will converge from a position near $A=0.5$ towards $A=2 / 3[3,4]$.

\section{Practical experiences}

We have used data from past events (controlled boils and boil related soil failures) for the purpose of a practical study of the propensity of sand boil formation with the help of grain distribution entropy. Data collection was broad based and we processed over 120 calculations from 104 grain distribution curves plotted for 12 locations (Tab. 1). Of the soil samples from the 12 test locations, the ones marked No. 4, originating from the dike failure at Hosszúfok, were from a location without a sand boil as the failure of the dike was caused by dispersive soil.

Tab. 1. The investigated soils

\begin{tabular}{lccc}
\hline No. & place & year & soil samples \\
\hline 1. & At Kutyatanya slice gate & 1987 & 5 \\
\hline 2. & Bölcske-Madocsai dike 79+415 section & 1965 & 17 \\
\hline 3. & Surány dike failure (photo 2, Fig. 6 & 1991 & 11 \\
\hline 4. & Hosszúfok dike failure & 1980 & 4 \\
\hline 5. & Mályvád reservoir 4+550 section & 1980 & 5 \\
\hline 6. & Maros great piping (photo 3) & 1970 & 8 \\
\hline 7. & At Karaszi-fok slice gate & 1986 & 14 \\
\hline 8. & Mosoni-Duna 9+250 section & 1991 & 14 \\
\hline 9. & Duna 23+700 section & 1965 & 14 \\
\hline 10. & VITUKI sand boil model soil & 1974 & 1 \\
\hline 11. & Dunafalva dike failure & 1954 & 7 \\
\hline 12. & Dunakiliti dike failure & 1954 & 4 \\
\hline
\end{tabular}

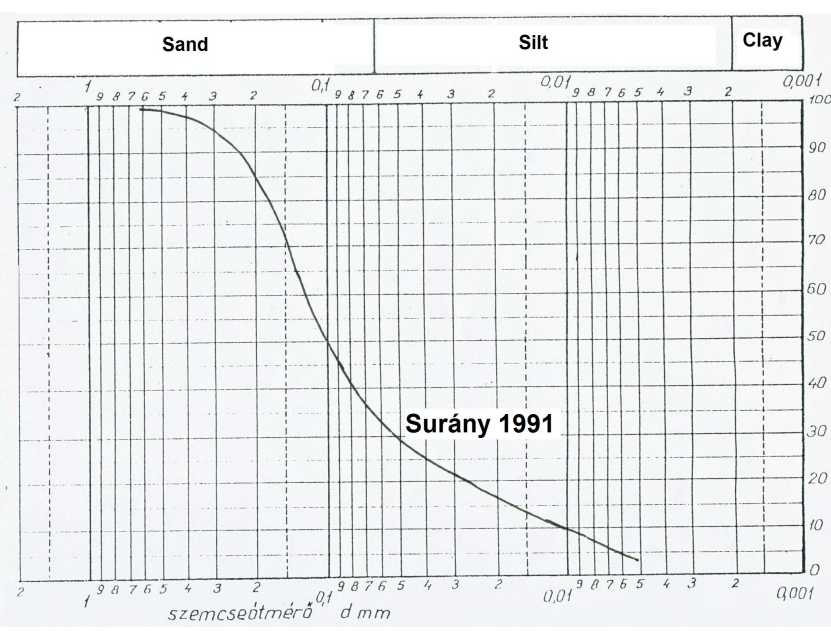

Fig. 6. The failed soil in Surány

From among the dike failures listed in Tab. 1 the failure at Surány (Fig. 7) is used to illustrate the results of our calculations. The breach occurred before midnight on August 5, 1991 most probably through hydraulic soil failure. The grain distribution curves of several soil mechanical drill holes lowered during the study of the circumstances of the breach are available (e.g. Fig. 6. Although a scour hole formed at the location of the dike breach and no sample could be obtained from the failed section (it had been washed away), we had to assume that the undamaged parts of the dike and the soils samples taken there represented local conditions accurately.

The grain distribution curves indicate that poorly graduated, finely grained soils classified as "stable" or "boil hazard" can be found below the stable silt, sand with sand meal and silt with sand meal and sand soils near the surface. The shape of the grain distribution curve of soils posing a "boil hazard" is mostly regular, and these soils contain 3-4 fractions when analysed for the purposes of an entropy test. The grain distribution curve indicates that these soils pose an erosion hazard and have a low boundary gradient of critical hydraulic failure and also pose subsoil failure hazard (Fig. 8).

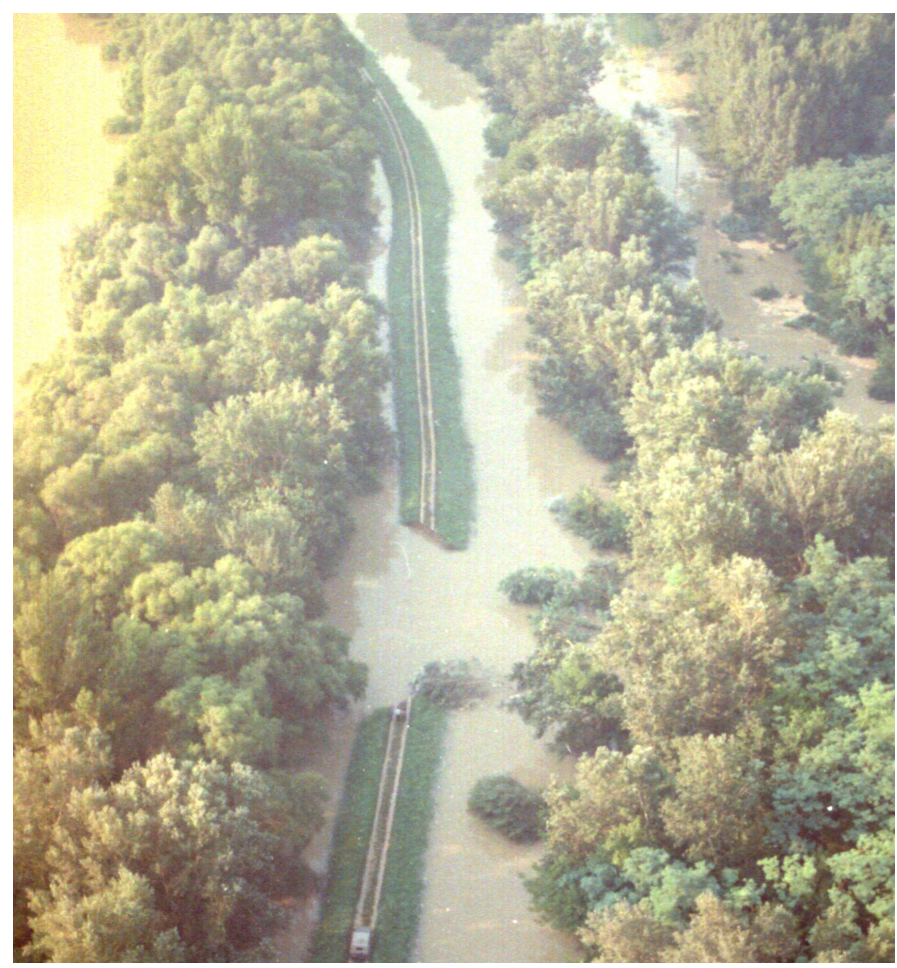

Fig. 7. The dike breach after peaking at Surány

The large sand boil of the Maros River also included a layer that had the propensity to boil based on grain distribution entropy. It is well known, though, that the large sand boil of the Maros River was described as "flow across the dike via a rotten tree root." However, the washout of grains was also observed, hence flood fighters rightly engaged in boil prevention. The definition of a sand boil is important from this perspective. For the purposes of fighting floods, it is practical to connect the concept of a sand boil with the washout of grains, or in other words it is grain washout that differentiates a boil from a flow across the dike. This corresponds to the practical guide of fighting floods, which requires protection against a boil whenever grain washout is observed on the protected side.

In summary of the analysis of entropy in practice we can assert that, except for a single instance (the samples of the disperse soil of the Hosszúfok dike failure, mentioned above) all of the analysed locations contained a layer of soil that had the propensity to boil. Simultaneously all of the samples taken from 


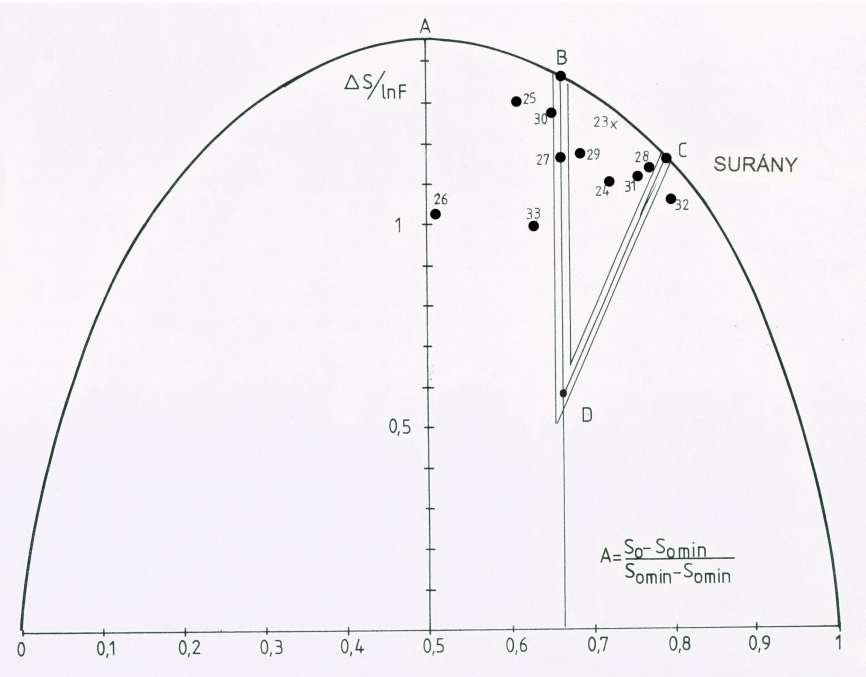

Fig. 8. The characterization of Surány soils by entropy

the Moson branch of the Danube at Dunafalva and Dunakiliti, i.e. from the upstream sections of the Danube in Hungary belonged to the range of soils that have the propensity to boil. Mention must be made of the fact that this result is the same that we know from experience: most of the sand boils were recorded in that area.

\section{Summary}

As regards the evaluation of various transient phenomena, the recognition that grain distribution curves contain the information needed for a "geometric" description of this set of occurrences is generally accepted. However, all entropy values, each of the points in Fig. 5 characterize a grain distribution curve of a certain shape and represent an infinite number of parallel grain distribution curves, since the calculation does not differentiate between clay and shingle with identical curve shapes.

Grain distribution entropy identifies soil type that have low entropy (a steep grain distribution curve) in quantifiable form and therefore pose the greatest boil hazard. That requires accurate grain distribution curves, though. A grain distribution analysis, however, is not capable of matching the accuracy required by mathematics in the range of silt-clay grains, hence valid boil hazard estimates are only possible when grain analysis relies on screening. Locations for which the measured values of a grain distribution curve are uncertain do not lend themselves to an accurate calculation of entropy. Grain distribution curves defined with or without chemicals may show significant differences, which will also influence entropy substantially [6,7].

Soil entropy values may be calculated from grain distribution curves. An entropy value characterises a grain distribution curve of a certain shape, i.e. a single entropy value represents a infinite number of parallel grain distribution curves. However, a grain distribution curve cannot be derived from an entropy value. As grain distribution curves contain more data than entropy values, it would be practical to retrace the information gathered from entropy studies into grain distribution curves. This could be done, for instance, with the help of a single distinguished point or value of grain distribution curves. Experience with the description of sand boil formation could be an important factor in selecting this point.

At present, knowledge concerning the process of sand boil formation and the internal and external factors leading on to soil failure is limited. We cannot define parameters of the criteria of sand boil formation, we cannot unambiguously determine in advance the location and the water level at which disaster is to be expected and we cannot recommend any other form of prevention but increasing the length of travel of the flow or closing the tube of the boil when flood levels keep increasing. Nevertheless, this series of tests is another step taken towards the full understanding of sand boil behaviour and the process of sand boil related soil failure. Although the studies relating to boil formation were intensively pursued in the seventies, they stopped completely in the eighties in Hungary. Now, after the turn of the millennium, it would be practical to revive our classified knowledge and apply our new level of awareness to increasing our understanding of sand boil related soil failures [6,7]. That would be necessary because recurring floods (see Fig. 1, 7, 97 force us to face this problem again and again.

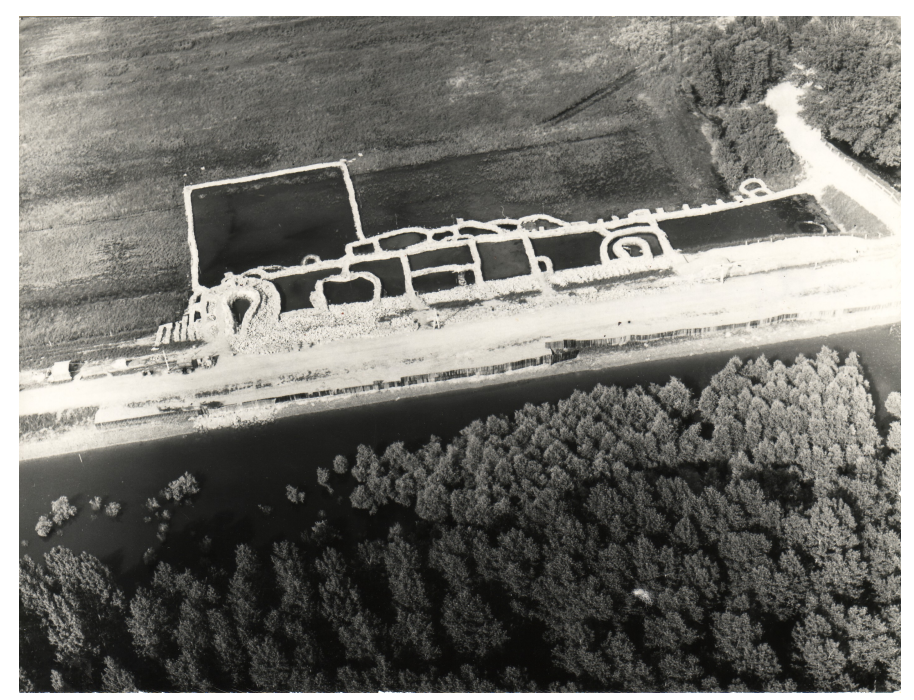

Fig. 9. The Maros great piping at Makó in 1970

Grain distribution entropy is a tool (at present for researchers only) that helps single out soils that have the propensity to form boils. This tool also helps identify the types of soil that require the smallest hydraulic gradient, the lowest amount of energy to get restructured through boiling. Bear in mind that all soils can be washed away provided the hydraulic gradient is sufficiently large and energy is sufficiently powerful.

Based on the above recommendations are formulated for continuing the research:

- When studying grain distribution, we frequently pay little attention to sampling itself. This paper also wished to highlight the reliability of grain distribution results. As the effectiveness of entropy tests depends fundamentally on the reliability of grain distribution data, it would be practical to learn more 
about the reliability of grain distribution curves from the perspective of sampling and screening-wet mechanical analysis, but the degree to which the results might help understand field processes is a question.

- At present, grain distribution entropy values are only suitable for determining the geometric potential of boil formation. Laboratory test findings would be needed to gain an understanding of the hydraulic conditions of this group of occurrences to create common ground for discussions about sand boil formation.

- Detailed studies would be needed about the substances washed out from sand boils along with comparisons to subsoil grain distribution curves. That could provide unquestionable evidence about whether a site is subject to suffusion or a boil. The data available for studying substances washed out of boils based on experience from previous floods are limited. It would therefore be useful to determine with the help of grain distribution entropy whether it is a single fraction that gets washed out of a soil or grain movement affects a complete layer.

\section{References}

1 Imre E, Rózsa P, Lörincz J, Characterization of some sand mixtures, 12th Int. Con. of Int. Association for Computer Methods and Advances in Geomechanics (IACMAG) (Goa, India, 2008), pp. 2064-2075.

2 Lőrincz J, Imre E, Gálos M, Trang Q P, Telekes G, Rajkai K, Grading entropy variation due to soil crushing, Second International Conference from Experimental Evidence Towards Numerical Modelling of Unsaturated Soils (Bauhaus-university, Weimar, Germany, 2003), pp. 215-231.

3 Lőrincz J, Soils grading entropy (Talajok szemeloszlási entrópiája), BME Civil engineering Faculty, Geotechnical Department, 1986.

4 , On particle migration with the help of grading entropy, Conf. on Filter sin Geotechnical and Hydraulic Engineering (Balkema, Rotterdam, The Netherlands, 1993), pp. 63-65.

5 Lőrincz J, Imre E, Gálos M, Trang Q P, Rajkai K, Fityus S, Telekes G, Grading Entropy Variation Due to Soil Crushing, International Journal of Geomechanics. ASCE December (2005), 311-319.

6 Lörincz J, Nagy L, Subsoil piping investigation of flood dikes with the help of grading entropy (Árvízvédelmi töltések altalajának vizsgálata buzgárosodásra való hajlam szempontjából a szemeloszlási entrópia segítségével), 1995.

7 _ Practical characterization of piping with the help of grading entropy. (Buzgárosodásra való hajlam gyakorlati vizsgálata szemeloszlási entrópia segítségével), Hidrológiai Közlöny 90 (2010), no. 3, 59-64.

8 Nagy L, Geotechnical problems of dikes (Az árvízvédelmi gátak geotechnikai problémái), Vízügyi Közlemények LXXXII. évf. (2000), no. 1, 121-146.

$9 \_$, Dike breaches in the Carpathian Basin, Periodica Polytechnica 50 (2004), no. 2, 115-124.

10 _ Investigation on Flood Embankment in Hungary, British-Hungarian Flood Control Workshop (1993), pp. 223-248. 